\title{
Towards inclusive education of children with Autism Spectrum Disorder. The impact of teachers' autism-specific professional development on their confidence in their professional competences
}

\author{
Joanna Kossewska ${ }^{1}$, Anna Bombińska-Domżał' ${ }^{2}$, Tamara Cierpiałowska ${ }^{2}$, \\ Elżbieta Lubińska-Kościółek ${ }^{2}$, Sylwia Niemiec ${ }^{2}$, Małgorzata Płoszaj ${ }^{1}$, David R. Preece ${ }^{3}$ \\ ${ }^{1}$ Institute of Psychology, Pedagogical University of Krakow, Poland \\ ${ }^{2}$ Institute of Special Education, Pedagogical University of Krakow, Poland \\ ${ }^{3}$ Centre for Education and Research, Faculty of Health, Education and Society, University of Northampton, UK
}

\begin{abstract}
HOW TO CITE:
Kossewska, J., Bombińska-Domżał,

A., Cierpiałowska, T., Lubińs-

ka-Kościółek, E., Niemiec, S.,

Płoszaj, M., Preece, D.R. (2021).

Towards inclusive education of children with Autism Spectrum Disor-

der. The impact of teachers'

autism-specific professional

development on their confidence

in their professional competences.

International Journal

of Special Education, 36(2), 27-35

CORRESPONDING AUTHOR:

Joanna Kossewska;

joanna.kossewska@up.krakow.pl

DOI:

https://doi.org/10.52291/ijse.2021.36.15
\end{abstract}

COPYRIGHT STATEMENT:

Copyright: () 2021 Authors.

Open access publication under the terms and conditions

of the Creative Commons

Attribution (CC BY)

license (http://creativecommons.

org/licenses/by/4.0/).

\begin{abstract}
:
Due to the shortage of autism-specific professional development, the international ASD-EAST project was implemented. This article presents the findings of a quantitative survey undertaken among Polish teachers (in two school settings: special, $\mathrm{N}=60$; mainstream/inclusive, $\mathrm{N}=30$ ) who attended ASD-EAST workshops. The aim was to identify the post-autism-specific professional development increase of teachers' knowledge concerning the characteristics of students with ASD and teachers' subjective confidence regarding their professional competencies. The results showed that the training opportunity was considered by teachers to be important and effective. The results provide grounds for concluding that the programme may be recommended for practical use in order to train teachers who will work with students with ASD.
\end{abstract}

Keywords: Autism Spectrum Disorders; autism-specific professional development; educational research; inclusive education. 


\section{INTRODUCTION}

The concept of promoting social diversity and acceptance of the fundamental rights of disabled children in European Union countries is starting to move away from segregated special education towards integrated or inclusive education. This has resulted in teachers facing increasingly complex challenges: in the process of transferring knowledge to students; in the implementation of educational tasks; and in supporting development through therapeutic activities. The inclusion of students with special educational needs within mainstream education requires that all teachers should have at least basic knowledge of special education and the therapeutic approaches used with disabled students.
Teachers' need for autism-specific professional development Due to the significance of the teacher in the development and education of students, it is crucial that teachers are appropriately and comprehensively prepared for their profession. Positive correlations between the level of teachers' professional knowledge and students' performance have been found (DeSimone, \& Parmar, 2006; Yoon et al., 2007). Moreover, teachers' knowledge and experience are key factors with regard to the effective education of students with ASD (Syriopoulou-Delli, Cassimos, Tripsianis, \& Polychronopoulou, 2012); the quality of work with students with ASD with the use of appropriate strategies (McGregor, \& Campbell 2001; Park, Chitiyo, \& Choi, 2010; Sanini, \& Bosa, 2015); and the formulation of appropriate expectations for stu-

\begin{tabular}{|c|c|}
\hline Modules & Content \\
\hline Communication & $\begin{array}{l}\text { Verbal and non-verbal communication processes } \\
\text { Expressive and receptive communication skills difficulties } \\
\text { Strategies, approaches and programmes to help teachers meet students' communicative needs } \\
\text { (e.g., PECS) } \\
\text { Ability to conduct a conversation (how, why, principles of conversation, starting and ending, tone of } \\
\text { voice, creating opportunities for communication, exercises) }\end{array}$ \\
\hline Social skills & $\begin{array}{l}\text { Social skills differences and deficits in ASD } \\
\text { Knowledge of basic techniques and tools for teaching social skills } \\
\text { Developing social skills (exemplary games and activities, role-playing, social thinking, social behaviour } \\
\text { mapping, social stories, comic book conversations) }\end{array}$ \\
\hline $\begin{array}{l}\text { Understanding } \\
\text { and managing } \\
\text { challenging } \\
\text { behaviours }\end{array}$ & $\begin{array}{l}\text { Reasons and functions of challenging behaviours } \\
\text { Direct and indirect assessment of behavioural function } \\
\text { Prevention and intervention strategies (e.g. adjusting the environment, teaching procedures, } \\
\text { teaching new skills, using visual aids) } \\
\text { Implementation of prevention and intervention strategies }\end{array}$ \\
\hline Sensory needs & $\begin{array}{l}\text { Sensory sensitivity threshold analysis } \\
\text { Comfort zone for the learning process } \\
\text { Sensory functions, needs and integration based on Dunn's model } \\
\text { Problems in sensory functioning of children with ASD } \\
\text { Assessment of sensory development of children } \\
\text { Sensory strategies for developing activities in the sensory room, the classroom, and beyond } \\
\text { Sensory diet creation }\end{array}$ \\
\hline $\begin{array}{c}\text { Emotional } \\
\text { understanding }\end{array}$ & $\begin{array}{l}\text { Emotional regulation } \\
\text { Difficulties in emotional regulation for children with ASD } \\
\text { Supporting students to identify and communicate changing emotional states } \\
\text { Identifying and implementing strategies to support students when experiencing uncomfortable } \\
\text { emotions } \\
\text { Developing the ability to self-regulate emotions (recognising emotions in oneself and others, } \\
\text { grading, scaling) }\end{array}$ \\
\hline $\begin{array}{l}\text { Adaptation and } \\
\text { modification of } \\
\text { environment }\end{array}$ & $\begin{array}{l}\text { Differentiation, adaptation and modification of the school environment and curriculum for children } \\
\text { with ASD } \\
\text { Identifying ways to assess the level of support students require and to measure the success of input } \\
\text { Adapting the learning environment to students' needs and communication ability } \\
\text { Structured teaching and adapting rules to students' needs }\end{array}$ \\
\hline
\end{tabular}

Source: Authors' research. 
dents regardless of the type of school (Rubie-Davies, 2007). However, many studies have shown that teachers' knowledge about autism is incomplete and their competencies are insufficient for them to successfully support children with autism in schools, especially in the mainstream (Loiacono, \& Valenti, 2010). Furthermore, teachers fully understand their significant position and the need for lifelong learning; therefore, they are motivated to continuously improve their competencies in the field of autism, regardless of their country of origin (Charman et al., 2011; McMillan, McConnell, \& O'Sullivan, 2016; Valdmann, Rannikmäe, \& Holbrook, 2016).

\section{Empowering teachers within the international ASD-EAST project}

Due to the shortage of appropriate ASD-related training opportunities for teachers in a number of European countries (Kossewska et al. 2019; Lessner Lištiaková, \& Preece, 2019; Lisak Šegota et al., 2020), an Erasmus+ strategic partnership (Autism Spectrum Disorder - Empowering and Supporting Teachers: ASD-EAST) was implemented in 2018-2020 in three European countries: Croatia, the Republic of North Macedonia, and Poland. In all these countries, there was a strong need for an autism-specific professional development programme to provide not only relevant theoretical information but also practical skills and strategies (Kossewska et al., 2019). Based on a literature review and analysis of teachers' self-identified training needs, this training programme comprised six discrete modules that were developed and delivered to two groups of teachers (special school teachers vs mainstream/inclusive school teachers) in the aforementioned countries. The general scope and content of the training program were almost stable, however, separate ASD-EAST workshops were held for teachers at special schools and mainstream/inclusive schools in reference to the level of support required (for non-speaking children with intellectual disabilities who attend special schools vs academically successful children from inclusive schools). Each module lasted 90 minutes and a range of didactic methods (lecture, discussion, presentation, video analysis, practical exercises) was used ${ }^{2}$. The scope of the content of the modules is presented in Table 1.

\section{Problems and research methods}

The survey was undertaken among teachers from Poland ${ }^{1}$ using quantitative methods developed within the ASDEAST project to identify (1) teachers' knowledge of how to teach and treat children with ASD, and (2) teachers' subjective confidence in their practical teaching skills and 3) the real-life outcomes three months after the training.

\section{Instrument}

A structured questionnaire was developed to collect the following: demographic data regarding the sample; teachers' knowledge of ASD students and their needs; teachers' experience and confidence in using specific approaches; teachers' autism-specific professional development needs.

In order to create this research paper, the questionnaire contained a 13-item scale related to the characteristics and educational needs of children with ASD; it also contained an 11-item scale related to teachers' subjective confidence in their practical teaching skills. The data were analysed using SPSS software.

\section{Respondents}

The questionnaire was distributed among teachers who participated in the autism-specific professional development programme delivered for two Polish subgroups (special school teachers and mainstream/inclusive school teachers) in November 2019 and January 2020. The announcement about the training was widely circulated via the internet on the ASD-EAST project website and the Pedagogical University of Krakow website; it was also distributed to schools in Małopolska Region and passed on between professional groups. The teachers for the autism-specific professional development subgroups were recruited from volunteers who had declared themselves willing to participate in all the autism-specific professional development programme modules $(6 \times 90 \mathrm{~min})$. These participants completed three questionnaires: a pre-workshop questionnaire, completed before training; a post-training questionnaire, completed immediately after training; and a follow-up questionnaire, completed three months after. Ninety primary schools (for 6(7)-12(14) years olds) teachers participated in the study: 60 from special schools (subgroup 1), and 30 from mainstream/inclusive settings (subgroup 2). All the teachers were female university graduates, qualified at MA level.

\section{RESULTS}

\section{Impact of autism-specific professional development on teach- ers' knowledge}

The impact of autism-specific professional development regarding the teaching approach to and treatment of children with ASD was identified by pre- and post-training evaluation. The teachers were surveyed regarding the teaching approaches and strategies used with children with ASD before the training and three months after it was completed. The results are presented in Table 2. 


\begin{tabular}{|c|c|c|c|c|}
\hline \multirow[t]{2}{*}{ Children with ASD } & \multicolumn{2}{|c|}{$\begin{array}{c}\text { Subgroup } 1 \\
\text { Special school teachers } \\
\text { pre-/post-training } \\
\text { differences }\end{array}$} & \multicolumn{2}{|c|}{$\begin{array}{c}\text { Subgroup } 2 \\
\text { Inclusive school teachers } \\
\text { pre-/post-training } \\
\text { differences }\end{array}$} \\
\hline & Z & $\mathrm{p}$ & Z & $\mathrm{p}$ \\
\hline \multicolumn{5}{|c|}{ benefit from: } \\
\hline early medical intervention & $-7.00(a)$ & 0.01 & $-4.48(a)$ & 0.01 \\
\hline early intervention & $-1.39(b)$ & 0.17 & $-3.27(b)$ & 0.01 \\
\hline early educational intervention & $0.01(c)$ & 1 & $-3.64(b)$ & 0.01 \\
\hline playing with their mainstream peers & $-2.83(b)$ & 0.01 & $0.77(\mathrm{a})$ & 0.44 \\
\hline \multicolumn{5}{|c|}{ present educational needs } \\
\hline for specialist educational approaches & $0.01(c)$ & 1 & $-2.46(b)$ & 0.01 \\
\hline to be educated in special schools & $0.01(c)$ & 1 & $-3.11(b)$ & 0.01 \\
\hline to be educated with mainstream peers & $-3.30(a)$ & 0.01 & $-3.61(a)$ & 0.01 \\
\hline \multicolumn{5}{|c|}{ progress and special talents } \\
\hline can be cured & $0.01(c)$ & 1 & $-3.75(a)$ & 0.01 \\
\hline cannot be cured but can be helped to have a better life & $-6.64(b)$ & 0.01 & $-0.62(b)$ & 0.53 \\
\hline can grow out of ASD & $0.01(c)$ & 1 & $-3.35(a)$ & 0.01 \\
\hline can be academically successful & $-1.63(a)$ & 0.10 & $-0.35(a)$ & 0.73 \\
\hline can have special gifts and talents & $-2.83(b)$ & 0.01 & $-1.38(a)$ & 0.17 \\
\hline can have challenging behaviours & $0.01(c)$ & 1 & $-3.00(b)$ & 0.01 \\
\hline
\end{tabular}

Source: Authors' research; Wilcoxon Signed Rank Test for dependent samples (pre- vs. post-training) from the two school settings (special school vs mainstream/inclusive school); (a) Based on positive ranks; (b) Based on negative ranks; (c) The sum of negative ranks equals the sum of positive ranks.

As Table 2 shows, attendance at the ASD-EAST workshops led to an increase in both groups' understanding that there is no effective medical treatment for ASD and that children with ASD can be effectively educated alongside their mainstream peers.

The attendance at the workshop further leads to an increase in the regular/inclusive school teachers' understanding regarding the importance of early childhood intervention (behavioural, therapeutic) and education for school-age children with ASD. Attendance also increased understanding of the benefits of specialised approaches; that ASD cannot be cured or that children might grow out of ASD; and that a special school setting may be appropriate for addressing their special educational needs. Teachers from mainstream/inclusive schools also developed a greater understanding of challenging behaviours.

In comparison, special school teachers saw the autism-specific professional development programme as a successful tool for increasing their understanding that children with ASD might benefit from playing with their mainstream peers and that although ASD cannot be cured, children with ASD can have special gifts and talents and can be helped to have a better life.

\section{Teachers' confidence}

The next measure of the effectiveness of autism-specific professional development concerned subjective confidence in supporting children with ASD (see Table 3).

The autism-specific initial/continuing professional development programme significantly increased teachers' subjective confidence; however, the results were found to be slightly different between the two subgroups (Table 3). The training was found to have a significant impact on the confidence of teachers from mainstream/inclusive settings in all the areas measured: working with families, cooperation with other teachers and external experts, supporting social interactions, peer relationships understanding and managing challenging behaviours, and establishing routines, providing support and access to the 


\begin{tabular}{|c|c|c|c|c|}
\hline \multirow[b]{2}{*}{$\begin{array}{l}\text { Autism-specific professional development enhanced } \\
\text { teachers' confidence in: }\end{array}$} & \multicolumn{2}{|c|}{$\begin{array}{c}\text { Subgroup } 1 \\
\text { Special school teachers } \\
\text { pre-/post-training } \\
\text { differences }\end{array}$} & \multicolumn{2}{|c|}{$\begin{array}{c}\text { Subgroup } 2 \\
\text { Inclusive school teachers } \\
\text { pre-/post-training } \\
\text { differences }\end{array}$} \\
\hline & Z & $\mathrm{p}$ & Z & $\mathrm{p}$ \\
\hline working in partnership with families of children with ASD & $-3.58(a)$ & .01 & $-4.76(a)$ & .01 \\
\hline $\begin{array}{l}\text { cooperation with teachers and other experts working } \\
\qquad \text { with children with ASD }\end{array}$ & $-5.56(b)$ & .01 & $-3.36(a)$ & .01 \\
\hline supporting communication of students with ASD & $-4.99(a)$ & .01 & $-4.75(a)$ & .01 \\
\hline supporting social interactions of students with ASD & $-5.14(a)$ & .01 & $-4.65(a)$ & .01 \\
\hline supporting peer relationships & $-6.87(\mathrm{a})$ & .01 & $-4.79(a)$ & .01 \\
\hline understanding reasons for/functions of challenging behaviours & $-1.41(b)$ & .16 & $-4.49(a)$ & .01 \\
\hline managing challenging behaviours & $-3.18(a)$ & .01 & $-4.74(a)$ & .01 \\
\hline providing support and access to the curriculum & $-.97(a)$ & .33 & $-4.55(a)$ & .01 \\
\hline establishing routines and supporting transitions & $-5.26(a)$ & .01 & $-4.41(a)$ & .01 \\
\hline supporting sensory needs & $-1.53(a)$ & .13 & $-4.51(a)$ & .01 \\
\hline understanding of emotions & $-2.90(a)$ & .01 & $-4.41(a)$ & .01 \\
\hline
\end{tabular}

Source: Authors' research; Wilcoxon Signed Rank Test for dependent samples (pre- vs. post-training) from the two school settings (special school and mainstream/inclusive school); (a) Based on negative ranks; (b) Based on positive ranks.

curriculum, understanding sensory needs. Significant improvements in the confidence of teachers from special schools were also identified in all but three areas: understanding the reasons for/functions of challenging behaviours, providing support and access to the curriculum, and supporting sensory needs.

\section{DISCUSSION}

As the identified prevalence of ASD has increased and the idea of schools for all students has become widespread, effective professional teacher development programmes specializing in ASD at both initial and continuing development levels are increasingly important. Previous studies have reported on attempts to develop training programmes for teachers who are preparing to work with students with ASD in inclusive schools (Barnhill, Sumukta, Polloway, \& Lee, 2014; Leblanc, Richardson, \& Burns, 2009; Morrier, Hess, \& Heflin, 2011; Probst, \& Leppert, 2008; Robinson, 2017; Shyman, 2012; Sobel, Iceman-Sands, \& Basile, 2007; Suhrheinrich, 2015; Yesim, 2013); even short training programmes based on scientific knowledge of ASD can promote a more realistic perception of ASD (Mavropoulou, \& Padeliadu, 2000).
Previous research identified Polish teachers' need to supplement their knowledge about ASD (Nowakowska, \& Pisula, 2018). Kossewska et al. (2019) identified the specific needs and wishes regarding the training of Polish teachers in Małopolska Voivodeship, on the basis of which a six-module (12 hours max) training programme was conducted which aimed to provide a basic range of professional knowledge and effective educational/therapeutic strategies. The training addressed the needs of teachers working in both special and mainstream schools. It allowed teachers to change their views on whether a child can be cured of ASD and improve their knowledge of the benefits of early educational/therapeutic interventions. After this training, teachers in mainstream/inclusive schools reported that they better understood the needs of students with ASD, but despite the acquisition of specific new knowledge and skills, they still believed that a special school setting is best for students with ASD. These results are consistent with those of researchers from other countries as, for organisational and professional reasons, special schools may often better meet the needs of students with ASD, especially those requiring more intensive support and a small number of students in the classroom (Autism and Education in England, 
2017; Barned, Knapp, \& Neuharth-Pritchett, 2011; Humphrey, \& Symes, 2013; Segall, \& Campbell, 2012; Yasar, \& Cronin, 2014). Teachers recognise that the education of children with ASD requires highly specialised competencies and - reflecting the findings of Loiacono and Valenti (2010) - teachers in mainstream schools in particular do not feel sufficiently prepared to work with this group of students even after intensive six-module training. This is also due to the fact that in the course of academic university studies, fewer than $50 \%$ of teachers in mainstream/inclusive schools become familiar with issues relating to ASD. This reflects the findings of a recent British study (Autism and Education in England, 2017) and is an important indicator of the assumption that there is an urgent and widespread need for teacher training in the field of ASD.

The results of the research are also consistent with previous studies (Ashburner, Ziviani, \& Rodger, 2010; Lane, Pierson, Stang, \& Carter. 2010; Mavropoulou, $\&$ Padeliadu, 2000), which suggest that special school teachers need more specific and specialised knowledge and skills to deal with the difficult behaviours they may face; to understand and meet students' sensory needs, and to develop their social and communication skills. The differences noted between the two groups of teachers may be due to the fact that students with ASD in special schools are under the control of more supportive autism-centered and child-focused teachers than children in mainstream schools. Due to their more limited experience of working with ASD children, teachers in mainstream/inclusive schools are more focused on the organisational aspects of working with children with ASD and adapting the environment to meet their sensory needs; moreover, schools need to prepare appropriately for the inclusive teaching of all students, which has only been an educational policy in Poland since $2017^{2}$.

The results further indicate that the presented training programme resulted in a change in attitudes towards students with ASD, as previously identified by McGregor and Campbell (2001). However, a more optimistic view of the social inclusion of children with ASD was only identified in teachers of special schools who noticed positive social outcomes of co-playing with typically developed children. It may be that these teachers are more aware of the negative consequences of the social segregation of disabled students than their mainstream/inclusive school colleagues. The training also had the positive effect of increasing teachers' confidence in their abilities and skills, which can be considered an indirect indicator of increased self-efficacy. This effect was also found in previous studies (Busby et al. 2012; Jennett, Harris, \& Mesibov, 2003; Vincent, \& Ralston, 2020). Self-efficacy has a positive effect on other areas of teaching: stress reduction in the case of challenging behaviour of students with ASD (Leblanc, Richardson, \& Burns, 2009; Lepper, $\&$ Probst, 2005), and reduction of the risk of professional burnout (Boujut, Dean, Grouselle, \& Cappe, 2016; Boujut et al., 2017; Corona, Christodulu, \& Rinaldi, 2016; Jennett, Harris, \& Mesibov, 2003; Ruble, User, \& McGrew, 2011). A sense of self-efficacy affects the formulation of appropriate expectations for students regardless of the type of school (special vs mainstream) (Rubie-Davies, 2007); it also improves the quality of work with students with ASD by increasing the effectiveness of appropriate educational strategies (McGregor, \& Campbell, 2001; Park, \& Chitiyo, 2011; Sanini, \& Bosa, 2015), and it increases the likelihood of students with ASD experiencing educational success through effective inclusion (Jennett, Harris, \& Mesibov, 2003; Busby et al., 2012; Rodriguez, Saladan, \& Moreno, 2012; Park, Chitiyo, \& Choi, 2010; Sanini, \& Bosa, 2015). The use of a non-standardised tool to measure teachers' confidence in their competencies (self-efficacy) resulted from the nature of the ASD-EAST project and the need to carry out intercultural comparisons, which otherwise would not have been possible due to the lack of adaptation of standardised tools in the countries being compared.

The training met the expectations of the participants in terms of the content of the programme, the scope of the content, and the right balance between theory and practice; in conclusion, the participants declared their willingness to recommend the training to their colleagues, which is an important indicator of the degree of satisfaction. The teachers implemented the strategies discussed in the aforementioned modules for their students within three months after the training. Special school teachers used strategies to deal with students with ASD who present a range of challenging behaviours and require significant support. In contrast, teachers in mainstream schools used strategies to develop social competences that, because of their versatility, were effective in improving the classroom performance, intra-group integration, and social understanding not only of students with ASD but of all students, regardless of their individual needs or developmental difficulties. Similar generalised positive effects for non-autistic students in the classroom were found by Higginson and Chatfield (2012). In their 
studies, teachers identified a number of specific strategies that were useful for the majority of the children in their classrooms.

\section{CONCLUSIONS}

The analysis presented in the article shows that professionally active teachers in special and inclusive schools have insufficient knowledge and skills to work with children with ASD. Therefore, there appeared to be a need to prepare a six-module training course within the ASDEAST project that would prepare teachers in mainstream/ inclusive and special schools to work with these students.

The impact analysis was based on subjective reports from participants, which is a significant limitation of the presented research. Further research into the impact and efficacy of training for teachers should take into account not only the subjective opinions of participants but also objectively measurable effects (e.g. increase in teachers' knowledge, increase in students' school skills and suc- cesses). Nonetheless, the findings of this study provide grounds for concluding that the programme may be recommended for practical use in order to train teachers who will work with students with ASD in an inclusive school setting.

\section{ACKNOWLEDGMENTS}

None.

\section{DISCLOSURE STATEMENT}

No potential conflict of interest was reported by the authors.

\section{FUNDING}

This work was supported by the European Commission under the Erasmus+ programme (grant number 2018-1-UK01KA201-047872). This aid does not constitute an endorsement of the contents, which reflect the views only of the authors, and the Commission cannot be held responsible for any use of the information contained therein which may be made available.

\footnotetext{
${ }^{2}$ http://asd-east.org/

${ }^{3}$ The evaluation process for the training, including the survey tools, was granted ethical approval by the University of Northampton's Research Ethics Committee on 1 March 2019.

${ }^{5}$ Regulation of the Minister of National Education of 9th August 2017 on the conditions for organising education, upbringing and care for disabled children and adolescents, socially maladjusted and endangered by social maladjustment § 7(2)(1), item 1578, and § 3 and 4 on specific qualifications required of teachers apply, item 1575 with amendments
}

\section{REFERENCES}

Autism and Education in England (2017). All Party Parliamentary Group on Autism Report. https://www.autism-alliance.org.uk/ wp-content/uploads/2018/04/APPGA-autism-and-education-report.pdf (retrieved 15.06.2020).

Ashburner, J., Ziviani, J., Rodger, S. (2010). Surviving in the mainstream: Capacity of children with autism spectrum disorders to perform academically and regulate their emotions and behaviour at school. Research in Autism Spectrum Disorders, 4 , 18-27. https://doi.org/j.rasd.2009.07.002.

Barned, N., Knapp, N., \& Neuharth-Pritchett, S. (2011). Knowledge and Attitudes of Early Childhood Preservice Teachers Regarding the Inclusion of Children With Autism Spectrum Disorder. Journal of Early Childhood Teacher Education. 32, 302321. https://doi.org/10.1080/10901027.2011.622235.

Barnhill, G., Sumukta, B., Polloway, E., \& Lee, E. (2014). Personnel preparation practices in ASD: A follow up analysis of contemporary practices. Focus on Autism and Other Developmental Disabilities, 29(1), 29-39.

Boujut, E., Dean, A., Grouselle, A., \& Cappe, É. (2016). Comparative Study of Teachers in Regular Schools and Teachers in Specialized Schools in France, Working with Students with an Autism Spectrum Disorder: Stress, Social Support, Coping Strategies and Burnout. Journal of Autism and Developmental Disorders. 46. https://doi.org/10.1007/s10803-016-2833-2.

Boujut, E., Popa-Roch, M., Palomares, E.A., Dean, A., \& Cappe, É. (2017). Self-efficacy and burnout in teachers of students with autism spectrum disorder. Research in Autism Spectrum Disorders, 36, 8-20. https://doi.org/10.1016/j.rasd.2017.01.002.

Busby, R., Ingram, R., Bowron, R., Oliver, J., \& Lyons, B. (2012). Teaching Elementary Children with Autism: Addressing Teacher Challenges and Preparation Needs, Rural Educator, 33(2), 27-35. 
Charman, T., Pellicano, L., Peacey, L. V., Peacey, N., Forward, K., \& Dockrell, J. (2011). What is good practice in autism education? London: UCL Institute of Education.

Corona, L.L., Christodulu, K.V.,\& Rinaldi, M.L. (2016). Investigation of School Professionals' Self-Efficacy for Working With Students With ASD: Impact of Prior Experience, Knowledge, and Training. Journal of Positive Behaviour Intervension. 19(2), 90-101. https://doi.org/10.1177/1098300716667604

DeSimone, J. R., \& Parmar, R. S. (2006). Middle school mathematics teachers' beliefs about inclusion of students with learning disabilities. Learning Disability Research \& Practice, 21(2), 98-110.

Higginson, R., \& Chatfield, M. (2012). Together We Can Do It: A Professional Development Project for Regular Teachers' of Children with Autism Spectrum Disorder. Kairaranga, 13(2), 29-40.

Humphrey, N., \& Symes, W. (2013). Inclusive education for pupils with autistic spectrum disorders in secondary mainstream schools: teacher attitudes, experience and knowledge. International Journal of Inclusive Education, 17(1), 32-46. https://doi. org/10.1080/13603116.2011.580462

Jennett, H. K., Harris, S. L., \& Mesibov, G. B. (2003). Commitment to philosophy, teacher efficacy, and burnout among teachers of children with autism. Journal of Autism and Developmental Disorders, 33(6), 583-593. https://doi.org/10.1023/ B:JADD.0000005996.19417.57

Kossewska, J., Preece, D., Bombińska-Domżał, A., Cierpiałowska, T., Lubińska-Kościółek, E., Niemiec, S., Płoszaj, M., Lessner Listiakova, I., Lisak, N., Stošić, J., Troshanska, J. (2019). Training needs in the field of autism by contemporary Polish teachers in the context of international ASD-EAST project. Social Welfare Interdisciplinary Approach, 9(1), 82-92.

Lane, K.L., Pierson, M.R., Stang, K.K., \& Carter, E.W. (2010). Teacher Expectations of Students' Classroom Behaviour. Remedial and Special Education, 31, 163-174.

Leblanc, L., Richardson, W., \& Burns, K. (2009). Autism Spectrum Disorder and the Inclusive Classroom: Effective Training to Enhance Knowledge of ASD and Evidence-Based Practices. Teacher Education and Special Education. 32(2), 166-179. https://doi.org/10.1177/0741932507334279.

Leppert, T., \& Probst, P. (2005). Development and evaluation of a psychoeducational group training programme for teachers of autistic pupils with mental retardation. Zeitschrift für Kinder- und Jugendpsychiatrie und Psychotherapie, 33, 49-58.

Lessner Lištiaková, I., \& Preece, D. (2019). In-service education and autism-specific continuing professional development for teachers regarding autism spectrum disorder: a review of the literature. Annales Universitatis Paedagogicae Cracoviensis: Studia Psychologica, 12, 177-199.

Lisak Šegota, N., Lessner Lištiaková, I., Stošić, J., Kossewska, J., Troshanska, J., Petkovska Nikolovska, A. Cierpiałowska, T. \& Preece, D. (2020). Teacher education and confidence regarding autism of specialist primary school teachers. European Journal of Special Needs Education. https://doi.org/10.1080/08856257.2020.1829865

Loiacono, V., \& Valenti, V. (2010). General Education Teachers Need to Be Prepared to Co-Teach the Increasing Number of Children with Autism in Inclusive Settings. International Journal of Special Education, 25(3) 24-32.

Mavropoulou, S., \& Padeliadu, S. (2000). Greek Teachers' Perception of Autism and Implications for Educational Practice: A Preliminary Analysis. Autism, 4(2), 173-183.

McGregor, E., \& Campbell, E. (2001). The attitudes of teachers in Scotland to the integration of children with autism into mainstream schools. Autism, 5(2), 189-207. https://doi.org/10.1177/1362361301005002008.

McMillan, D.J., McConnell, B., \& O'Sullivan, H. (2016). Continuing professional development - why bother? Perceptions and motivations of teachers in Ireland. Professional Development in Education, 42(1), 150-167. https://doi.org/10.1080/194152 57.2014 .952044

Morrier, M., Hess, K., \& Heflin, L. (2011). Teacher training for implementation of teaching strategies for students with autism spectrum disorders. Teacher Education and Special Education The Journal of the Teacher Education Division of the Council for Exceptional Children, 34, 119-132.

Nowakowska, I., \& Pisula, E. (2018). Wiedza na temat zaburzeń ze spektrum i opinie dotyczące edukacji włączającej dzieci z tymi zaburzeniami u nauczycieli szkół podstawowych oraz studentów kierunków nauczycielskich. Człowiek - NiepełnosprawnośćSpołeczeństwo, 2(40), 29-48.

Park, M. \& Chitiyo, M. (2011), An examination of teacher attitudes towards children with autism. Journal of Research in Special Educational Needs, 11, 70-78. https://doi.org/10.1111/j.1471-3802.2010.01181.x

Park, M., Chitiyo, M., \& Choi, Y. (2010). Examining pre-service teachers' attitudes towards children with autism in the USA. Journal of Research in Special Educational Needs, 10, 107-114. https://doi.org/10.1111/j.1471-3802.2010.01150.x

Probst, P., \& Leppert, T. (2008). Brief report: Outcomes of a teacher training program for autism spectrum disorders. Journal of Autism Development Disorders, 38, 1791-1796.

Robinson, D. (2017). Effective inclusive teacher education for special educational needs and disabilities: Some more thoughts on the way forward. Teaching and Teacher Education, 61, 164-178. https://doi.org/10.1016/j.tate.2016.09.007

Rodriguez, I.R. Saldana, D., \& Moreno, F.J. (2012). Support, inclusion and special education. Teachers' attitudes toward the education of students with autism spectrum disorders, Autism Research and Treatment, 1, 5-6.

Rubie-Davies, C. (2007). Classroom interactions: Exploring the practices of high- and low-expectation teachers. The British Journal of Educational Psychology, 77, 289-306. https://doi.org/10.1348/000709906X101601

Ruble, L., \& Usher, E., \& Mcgrew, J. (2011). Preliminary Investigation of the Sources of Self-Efficacy Among Teachers of Students with Autism. Focus on Autism and other Developmental Disabilities, 26, 67-74. https://doi.org/10.1177/1088357610397345

Sanini, C., \& Bosa, C.A. (2015). Autismo e inclusão na educação infantil: Crenças e autoeficácia da educadora. Estudos de Psicologia, 20. https://doi.org/10.5935/1678-4669.20150019 
Segall, M.,\& Campbell, J. (2012). Factors relating to education professionals' classroom practices for the inclusion of students with autism spectrum disorders. Research in Autism Spectrum Disorders, 6, 1156-1167. https://doi.org/10.1016/j. rasd.2012.02.007

Shyman, E. (2012). Teacher Education in Autism Spectrum Disorders: A Potential Blueprint. Education and Training in Autism and Developmental Disabilities, 47(2), 187-197.

Sobel, D., Iceman-Sands, D., \& Basile, C. (2007). Merging general and special education teacher preparation programs to create an inclusive program for diverse learners. New Educator, 3(3), 241-262. https://doi.org/10.1080/15476880701484113

Suhrheinrich, J. (2015). A sustainable model for training teachers to use pivotal response training. Autism, 19(6), 713-723.

Syriopoulou-Delli C.K., Cassimos D.C., Tripsianis G.I., \& Polychronopoulou S.A. (2012). Teachers' Perceptions Regarding the Management of Children with Autism Spectrum Disorders. Journal of Autism and Developmental Disorders, 42, 755-768. https://doi.org/10.1007/s10803-011-1309-7

Valdmann, A., Rannikmäe, M., \& Holbrook, J. (2016). Determining the effectiveness of a CPD programme for enhancing science teachers' self-efficacy towards motivational context-based teaching. Journal of Baltic Science Education, 15(3), $284-296$.

Vincent J., \& Ralston K. (2020). Trainee teachers' knowledge of autism: implications for understanding and inclusive practice. Oxford Review of Education, 46(2), 202-221. https://doi.org/10.1080/03054985.2019.1645651

Yasar, P., \& Cronin, K.A. (2014). Perspectives of college of education students in Turkey on autism spectrum disorders. International Journal of Special Education, 29(1), 61-75.

Yesim, A. (2013). A Training Programme for a Teacher Working with a Student with ASD: An Action Research. Educational Sciences: Theory \& Practice. 13, 1-18. https://doi.org/10.12738/estp.2013.4.1738

Yoon K.S., Duncan T., Lee S.W.Y., Scarloss B., \& Shapley K. (2007). Reviewing the evidence on how teacher professional development affects students achievement, Washington. https://ies.ed.gov/ncee/edlabs/regions/southwest/pdf/ $\underline{\text { REL 2007033.pdf }}$ 